\title{
Analysis of Thermal Performance Improvement of Residential Building: A Case Study in an Urban Bhutan
}

\author{
Tshewang Lhendup Tibinda Powdel \\ Centre for Renewable and Sustainable Energy Development, Electrical Engineering Department \\ College of Science and Technology, Royal University of Bhutan, Rinchending, Bhutan
}

\begin{abstract}
This paper presents an estimate of the level of energy efficiency that could be achieved through improvement in building envelope. A residential flat in Thimphu, Bhutan was simulated in transient simulation software TRNSYS with measured weather data. From the simulation, it was observed that the thermal energy demand of the flat could be reduced between $11-64 \%$ by insulating the building envelopes under various scenarios. The simulation result suggests that attic insulation must be the first method to look into while deciding for retrofitting a poorly performing building as it could result in a high reduction of annual heating energy demand. The simulation shows that maximum heating energy demand reduction (64\%) could be achieved when attic and wall insulation was used. Keywords- Building thermal performance, TRNSYS, energy analysis, energy savings, thermal energy
\end{abstract}

DOI: $10.7176 / \mathrm{JEP} / 11-27-14$

Publication date:September $30^{\text {th }} 2020$

\section{Introduction}

The main focus of today's energy-intensive world is energy conservation and energy efficiency. Energy conservation does not necessarily require high-end technology for implementation. However, with the advancement in technology, the method of energy conservation has improved. Switching off of an electric lamp in an unused room in a home is an act of energy conservation. These days, everything is possible with a mere tap on an application on the phone with the help of the concept of IoT (Internet of Things). These scientific advancements have facilitated easier conservation of energy and an efficient system that provides improved energy output with minimal losses of energy. Therefore, the tradeoffs between the benefits of such technologies are required to be assessed.

Bhutan located in the Himalayas has three climatic zones; alpine, temperate, and subtropical. The climate varies according to altitude. The altitude ranges from 300 m.a.s.l in the south to 3500 m.a.s.l in the north. The southern foothills have a subtropical humid climate, while it is temperate in the central inner Himalayas and cold in northern parts with snow-covered mountains in winter. The building sector in Bhutan contributes $36 \%$ of final energy consumption globally (IEA, 2019). The energy consumption in the building sector has increased due to better access to energy and increase in the use of energy-consuming devices. Further due to advancements in technology and rapid growth in building constructions, such consumption is expected to increase. The building sector in Bhutan contributed to about $42 \%$ of total energy consumption in the country in 2014 with the residential sector alone consuming about $79 \%$ of total energy in the building sector (DRE, 2015). The study also states that Thimphu consumed the highest amount of electricity in the building sector with maximum consumption in the urban residential sector.

A study by Jentsh et al. (2017) concluded building material properties of some common buildings in Thimphu that the current houses in the city could be classified as leaky with infiltration rates of about 3.9 to $5.3 \mathrm{ACH}$ for traditional-style houses and 0.8 to $1.9 \mathrm{ACH}$ for modern constructions. The energy losses taking place during the heating season could be judged by studying these values. The U-values of the common type of brick infill walls were found to be 1.25 to $1.45 \mathrm{~W} / \mathrm{m}^{2} \mathrm{~K}$ and that of traditional rammed earth walls as 1.1 to $1.2 \mathrm{~W} / \mathrm{m}^{2} \mathrm{~K}$ and the cement stabilized earth walls at 1.05 to $1.25 \mathrm{~W} / \mathrm{m}^{2} \mathrm{~K}$. The same study indicates that most houses in the country perform poorly contributing to losses in heating energy.

It is important to look into the design of construction of building envelope. The methods of a building envelope include adequate insulation, window glazing, and airtightness of the rooms. HVAC systems play an important role in maintaining a healthy indoor environment in a building. If exhaust fans or forced ventilation is used, it would significantly impact the thermal performance of a building by driving the heated air out. However, in Bhutan most residential buildings do not have HVAC systems installed. The residents employ natural ventilation through permanent openings on the walls in most homes in southern warmer regions and little or no openings in cold regions to avoid infiltration of cold air in winter. If ventilations are required, the windows are opened as and when required by the occupants. As there are no comprehensive studies on the effectiveness of the insulation on the building energy demand, this paper presents the improvement of the thermal performance of a typical urban residential building in a cold climate to ascertain energy-efficient alternatives that are financially viable for the construction. 


\section{Methodology}

A sample building was selected and a simulation-based analysis from archived data available on a modern residential building was used to carry out the study. This selected building is ideal for this case study because it represents the majority of the type of urban dwellings in Thimphu as well as other cities in the country. The Bhutan Living Standard Survey reported that $36.8 \%$ of the households live in houses with cement-bonded brick or stone wall (NSB, 2017). Likewise, $95 \%$ of households use metal sheets as a roofing material (NSB, 2017). The building considered in this case study is a three-storied residential building with two flats per storey. The selected building is a privately-owned residential building located in the capital city, Thimphu. Since the measured air temperature and humidity data for the study was available for only two rooms of a single unit on the third floor, a single unit was modeled.

\subsection{Location}

The case building is located at $27.50^{\circ} \mathrm{N}, 89.63^{\circ} \mathrm{E}$, and an elevation of 2384 meters above sea level. The sketch of the flat in Figure 1 shows different zones considered in this case study. The different zones are Bedroom (BR), Choesham (CH), Master Bedroom (MBR), Master Toilet (MT), Toilet (T), Kitchen (K) and partially above zone Living Room (LR).

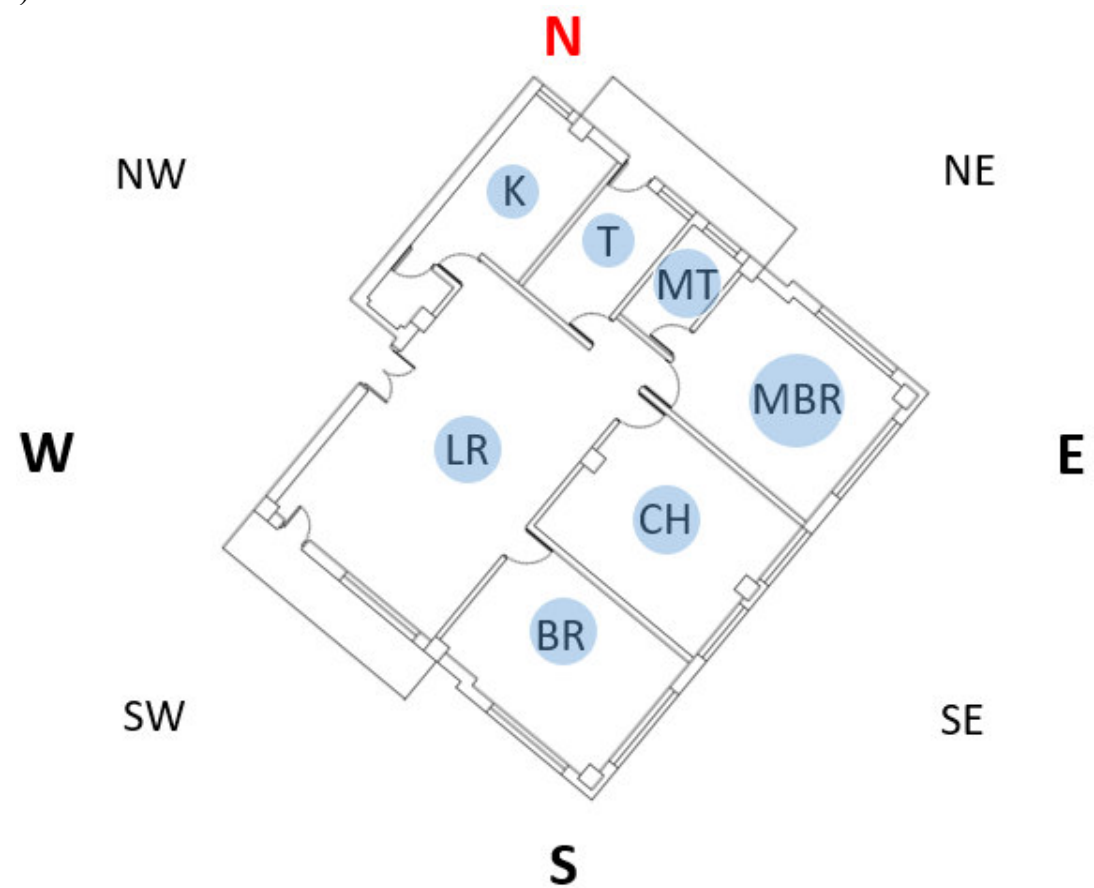

Figure 1. Orientation of the building with zone location

\subsection{Building Envelope}

The case building is constructed with bricks and concrete mortar supported by reinforced cement concrete structure and corrugated iron pitched roof. The building has 10 thermal zones as presented in Table 1.

Table 1. Thermal zones of the building

\begin{tabular}{|c|l|c|c|}
\hline Sl. No. & \multicolumn{1}{|c|}{ Zone Name } & Zone Volume $\left.\mathbf{( m}^{\mathbf{3}}\right)$ & Code Name \\
\hline 1 & Living room & 102.33 & LR \\
\hline 2 & Bedroom & 42.99 & BR \\
\hline 3 & Choesham (Alter room) & 47.12 & CH \\
\hline 4 & Master Bedroom & 47.12 & MBR \\
\hline 5 & Master Toilet & 10.65 & MT \\
\hline 6 & Toilet & 22.77 & T \\
\hline 7 & Kitchen & 29.47 & K \\
\hline
\end{tabular}

The floor is constructed of a concrete slab with wood flooring except for bathrooms where tile flooring is used. The composition of the floor and the parameters of the floor are presented in Table 2. 
Table 2. Properties of the floor material

\begin{tabular}{|l|l|c|c|c|c|}
\hline \multirow{2}{*}{ Type } & \multicolumn{1}{|c|}{ Layers } & $\begin{array}{c}\text { Conductivity } \\
(\mathbf{k J} / \mathbf{h . m . K})\end{array}$ & $\begin{array}{c}\text { Specific heat capacity } \\
\mathbf{( k J / k g K )}\end{array}$ & $\begin{array}{c}\text { Density } \\
\left(\mathbf{k g} / \mathbf{m}^{\mathbf{3}} \mathbf{)}\right.\end{array}$ & $\begin{array}{c}\text { Thickness } \\
(\mathbf{m m})\end{array}$ \\
\hline \multirow{3}{*}{$\begin{array}{l}\text { Bathroom } \\
\text { Floor }\end{array}$} & Tiles & 3.02 & 0.92 & 1922 & 6 \\
\cline { 2 - 6 } & Cement mortar & 5.04 & 1 & 2000 & 5 \\
\cline { 2 - 6 } & Concrete slab & 4.068 & 1 & 1400 & 150 \\
\hline \multirow{2}{*}{ Room Floor } & Wood & 0.36 & 2.09 & 506 & 25.4 \\
\cline { 2 - 6 } & Concrete slab & 4.068 & 1 & 1400 & 150 \\
\hline
\end{tabular}

There are two different types of wall, external and internal. The external wall covers the external envelope and is thicker than the internal walls that separate the different zones internally. The composition of walls and the calculation parameters of the walls are given in Table 3 .

Table 3. Properties of the wall material

\begin{tabular}{|c|l|c|c|c|c|}
\hline \multirow{2}{*}{ Type } & \multicolumn{1}{|c|}{ Layers } & $\begin{array}{c}\text { Conductivity } \\
\text { (kJ/(h.m.K)) }\end{array}$ & $\begin{array}{c}\text { Specific heat } \\
\text { capacity (kJ/(kg.K)) }\end{array}$ & $\begin{array}{c}\text { Density } \\
\left(\mathbf{k g} / \mathbf{m}^{\mathbf{3}}\right)\end{array}$ & $\begin{array}{c}\text { Thickness } \\
(\mathbf{m m})\end{array}$ \\
\hline \multirow{2}{*}{ External wall } & Cement mortar & 5.04 & 1 & 2000 & 5 \\
\cline { 2 - 6 } & Bricks & 2.92 & 0.92 & 1731 & 250 \\
\hline \multirow{3}{*}{ Internal wall } & Wood & 0.36 & 2.09 & 506 & 25.4 \\
\cline { 2 - 6 } & Cement mortar & 5.04 & 1 & 2000 & 5 \\
\cline { 2 - 6 } & Bricks & 2.92 & 0.92 & 1731 & 125 \\
\hline
\end{tabular}

The ceiling is made up of $8 \mathrm{~mm}$ thickness plywood. The composition of the ceiling and the calculation parameters of the walls are shown in Table 4.

Table 4. Properties of the ceiling material

\begin{tabular}{|l|l|c|c|c|c|}
\hline \multicolumn{1}{|c|}{ Type } & \multicolumn{1}{|c|}{ Layers } & $\begin{array}{c}\text { Conductivity } \\
(\mathbf{k J} / \mathbf{h . m . K})\end{array}$ & $\begin{array}{c}\text { Specific heat } \\
\text { capacity } \mathbf{( k J / k g . K )}\end{array}$ & $\begin{array}{c}\text { Density } \\
\left(\mathbf{k g} / \mathbf{m}^{\mathbf{3}}\right)\end{array}$ & $\begin{array}{c}\text { Thickness } \\
(\mathbf{m m})\end{array}$ \\
\hline Ceiling Ply & Plywood & 0.54 & 1.2 & 800 & 8 \\
\hline Ceiling slab & Concrete slab & 4.068 & 1 & 1400 & 150 \\
\hline
\end{tabular}

The roof is made out of corrugated iron. It is the same on the entire roof of the building. The properties of the roof material are presented in Table 5.

Table 5. Property of roofing material

\begin{tabular}{|c|c|c|c|c|c|}
\hline Type & Layers & $\begin{array}{c}\text { Conductivity } \\
(\mathbf{k J} / \mathbf{h} . \mathbf{m} . \mathbf{K})\end{array}$ & $\begin{array}{c}\text { Specific heat } \\
\text { capacity }(\mathbf{k J} / \mathbf{k g} . \mathbf{K})\end{array}$ & $\begin{array}{c}\text { Density } \\
\left(\mathbf{k g} / \mathbf{m}^{\mathbf{3}}\right)\end{array}$ & $\begin{array}{c}\text { Thickness } \\
(\mathbf{m m})\end{array}$ \\
\hline Roof & Corrugated iron & 219 & 0.5 & 7850 & 1.5 \\
\hline
\end{tabular}

Single glazed type of window with a U-value of $5.8 \mathrm{~W} / \mathrm{m}^{2} \mathrm{~K}$ was used from the standard library on all walls of the zones.

\subsection{Building Operation Characteristics}

\subsubsection{Heating, cooling and ventilation}

There is no record of heating element used in the measurement and gain from heating was assumed. The heating power for the rooms was assumed since the power rating and operation schedule for the heating system were not known. The HVAC system is also not used in the building; therefore, no cooling or ventilation was used in this simulation.

\subsubsection{Infiltration}

The airtightness of a building envelope is done using a blower door test. As it was not feasible to conduct this test and hence, values were assumed. Infiltration is expected from doors and windows in the living zones. The building does not have an artificial ventilation system. Natural ventilation is used for such buildings by opening the windows. In this paper, a constant infiltration value of $1.0 \mathrm{ACH}$ at normalized value from $50 \mathrm{~Pa}$ pressure was considered for all the zones.

\subsubsection{Internal heat gains}

Internal heat gains from occupants, lighting and room heater were used in this simulation. The gains from occupants were selected from the standard table ISO 7730 in the Gains window for the individual zone in TRNBuild. The degree of activity for occupants was selected to be 'seated at rest' and coupled with the daily occupancy schedule of the particular zone. The heating season was coupled with the zone occupancy schedule to get the heating schedule of individual zones. Figure 2 shows the living room and annual heating seasons used in the simulation. Figure 3(a) shows the actual occupancy of the living room and Figure 3(b) shows the lighting schedule for the living room. 

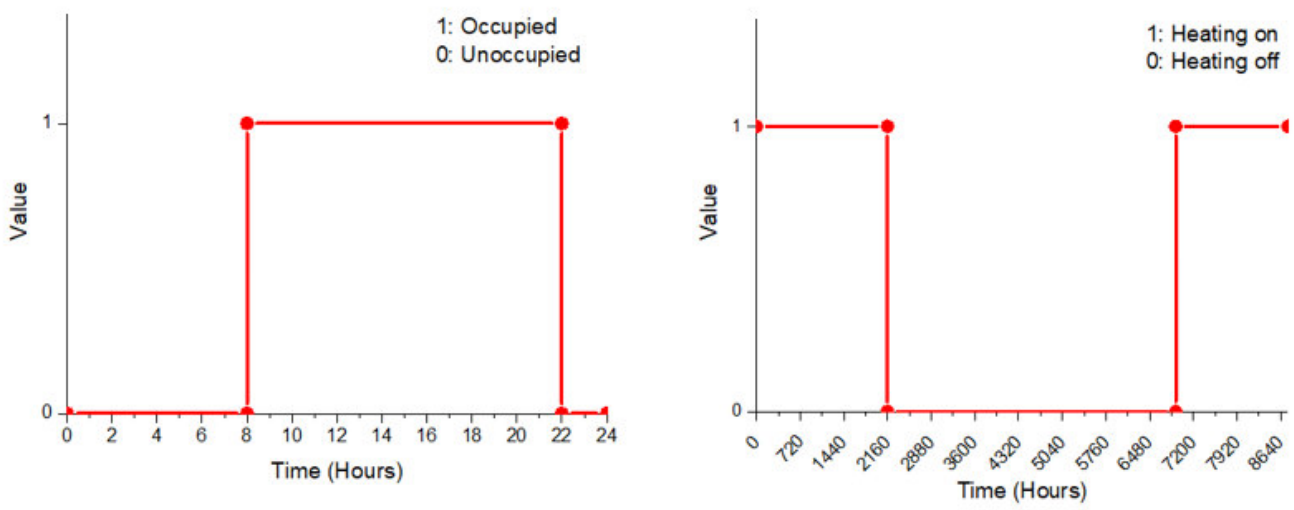

Figure 2(a) daily heating schedule for living room and (b) annual heating schedule
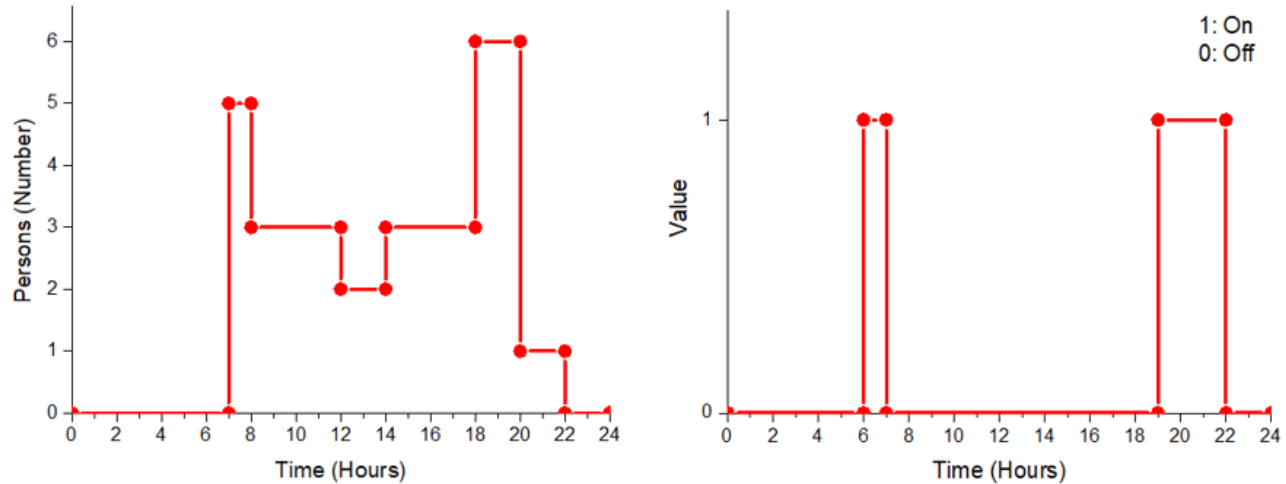

Figure 3. Living room schedule for (a) occupancy (b) lighting

\subsection{Building Modeling in TRNBuild}

TRNBuild is an integrated platform in TRNSYS to model a building upon the building description and other data parameters. It offers an interactive platform to input building descriptions from orientation to material thickness. The description of the building was input in the TRNBuild platform to generate a building input file (.BUI) for simulation which is used by the Type56 component in TRNSYS.

TRNSYS, transient simulation software is the user interface platform where different components could be interconnected to build a simulation. In the simulation studio, the output from building data was fed to the TYPE56 component. This component takes various parameters such as weather data and other user-defined inputs to compute and simulate the building's operation and provides outputs that the user might have defined earlier in TRNBuild. The simulation was run for one year (8760 hours) using measured weather data for the year 2017.

\subsection{Energy analysis}

Chimack, Walker \& Franconi (2001) suggested that for the whole building simulation, the Normalized Mean Bias Error (NMBE) and Coefficient of Variation of the Root Mean Square Error (CVRMSE) were calculated for validation of the model along with monthly error $\left(E R R_{\text {month }}\right)$ and yearly error $\left(E R R_{\text {year }}\right)$ to compare measured and simulated energy consumption. However, in this paper, measured energy data was not available to compare with the simulation. Therefore, air temperature data were used to validate the model.

To calculate the energy demand when the thermal insulation was employed in the existing building, building energy demand was used. The reduction in energy demand was calculated from the base case scenario for other energy-efficient scenarios. The energy demand per unit area of the building was calculated to compare later with the energy cost per unit area of thermal insulation.

\subsection{Financial calculation}

The energy demand reduction due to insulation was used to calculate the cost saved on energy by the installation of thermal insulation. The cost saved per unit area of the room was determined to compare and calculate the simple payback period for such a combination of insulation measures as defined by different insulation schemes created. This would give an estimate of the minimum number of years that the return on investment in such measures will provide. The cost of installation per unit area including material cost is presented in Table 6. A simple payback method was used to estimate the early recovery from different energy efficiency schemes which is defined below.

$$
S P P_{\text {Year }}=\frac{\text { Project cost }}{\text { Annual cash flow }}
$$


The payback period is the time required to recover the amount invested in an asset from its net cash flows (Accounting Tools, 2019). This method does not include factors of actual economics of the project such as life span, additional cash flows, time value of money, etc. and neither it is used in this analysis for reasons explained. To compare the net cash flow and investment, cost savings in energy per year is used with investment in insulation measured for every scenario.

The formula for calculating the payback period was thus used as below:

$$
S P P_{\text {Year }}=\frac{\text { Investment cost of insulation scheme per unit are a } \text { of insulation }}{\text { Annual savings in costs per unit area of room }}
$$

Zhivov, et al. (2015) conclude that retrofitting techniques individually is economically not desirable as compared to when done in combination with major building renovation technology. Straube, et al. (2012) states that the benefit from insulation diminishes with increasing thickness in insulation and it is usually related to insulation cost and climate condition.

Table 6. Cost per unit area of installing insulation (India Mart, 2019) (India Mart, 2019)

\begin{tabular}{|l|c|c|c|}
\hline \multicolumn{1}{|c|}{ Material } & Unit & Per unit cost & Cost of installation $\mathbf{( N u / \mathbf { m } ^ { 2 } )}$ \\
\hline Rock wool & $\mathrm{m}^{2}$ & 180 & 180 \\
\hline XPS & $\mathrm{m}^{2}$ & 450 & 450 \\
\hline Gypsum board & $\mathrm{m}^{2}$ & 325 & 325 \\
\hline Gypsum plaster & $\mathrm{kg}$ & 5.8 & 162.4 \\
\hline
\end{tabular}

\section{Results and Discussion}

\subsection{Model Validation}

The living room air temperature was used to validate the model. To compare them, the output of TRNSYS was matched with the measured data. The error margins were calculated as below to check the acceptance level as suggested in ASHRAE 14-2014. The calculated Nominal Mean Bias Error and Coefficient of Variation of Root Mean Square Error are presented in Table 7.

Table 7. Calibration result of building simulation

\begin{tabular}{|l|c|}
\hline \multicolumn{1}{|c|}{ Error } & Living room \\
\hline NMBE & $8.29 \%$ \\
\hline CVRMSE & $20.79 \%$ \\
\hline Correlation coefficient & $88.83 \%$ \\
\hline
\end{tabular}

As suggested the accepted level or error is NMBE: $<10 \%$ and CVRMSE $<30 \%$ for hourly data. In Table 7 , it is evident that both the CVRMSE values are within the limits. The model could be calibrated further to obtain the best plot of resemblance but the parameters could be varied only so much after which it loses the sense of practicality. In this case, increasing the zone thermal capacitance reduced the graph peaks and match the measured plot. However, the value of zone thermal capacitance could not be increased beyond a certain value. Increasing the thermal capacitance value beyond the point did not make practical sense.

\subsection{Energy Analysis}

In the base case scenario (without insulation), the calibrated model was simulated to generate the monthly energy demand for the building to maintain a livable room air temperature of $18^{\circ} \mathrm{C}$. The total annual energy demand for the building was $12,491 \mathrm{kWh}$ without any insulation on the building envelope. Figure 4 shows the hourly variation in room temperature of the living room when heating was used to maintain a minimum temperature of $18^{\circ} \mathrm{C}$ for one year. The living room air temperature does not go below $18^{\circ} \mathrm{C}$ throughout the heating season. When the room temperature decreases, the heating demand increases to maintain the set temperature. 


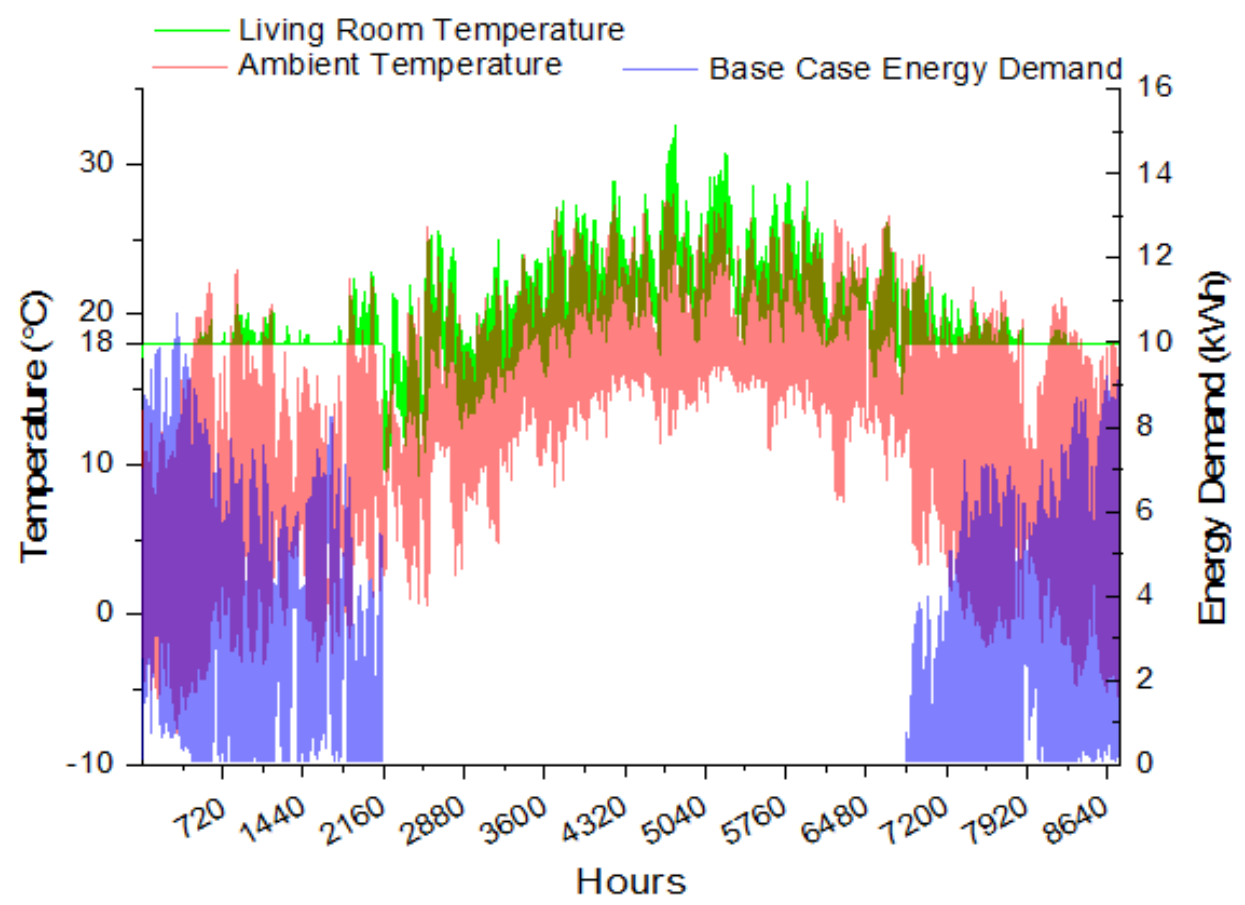

Figure 4. Energy demand and room temperature for the base case scenario

The energy demand for the entire heating season for different insulation schemes is summarized in Figure 5. It is worth noting that insulation was applied to external walls of the heated rooms only for assuming easy and cheap practical application of retrofitting. Besides, the internal walls or adjacent walls were not insulated to use the walls as thermal storage. Table 8 shows the summary of energy demand variation and consequent energy demand reduction with different scenarios simulated.

Table 8. Energy demand and percentage reduction in energy demand for all scenarios

\begin{tabular}{|l|l|c|c|}
\hline \multicolumn{1}{|c|}{ Scenario } & \multicolumn{1}{|c|}{ Insulation method } & $\begin{array}{c}\text { Energy demand } \\
(\mathbf{k W h})\end{array}$ & $\begin{array}{c}\text { Energy reduction } \\
(\mathbf{\%})\end{array}$ \\
\hline Base case & No insulation & 12491.55 & - \\
\hline Scenario-1 & Attic & 6894.11 & 45 \\
\hline Scenario-2 & Internal side of external wall & 11067.73 & 11 \\
\hline Scenario-3 & External side of external wall & 10626.38 & 15 \\
\hline Scenario-4 & Attic and internal side of external wall & 4938.64 & 60 \\
\hline Scenario-5 & Attic and external side of external wall & 4588.56 & 63 \\
\hline
\end{tabular}

The heat loss through the attic is significant at $45 \%$ reduction in energy demand. Attic insulation would result in significant energy saving in terms of space heating. The simulation result suggests that attic insulation must be the first method to look into while deciding for retrofitting a poorly performing building. The simulation shows that maximum energy demand reduction is obtained when attic and wall insulation was used. When attic insulation was used with the internal side of the wall insulation, energy-saving was the highest.

The external insulation proved to be marginally better than internal insulation. It could be because external insulation covers the building envelope better as the internal part of the walls was used as thermal storage as compared to insulation on the internal side of the external walls. While insulating the walls internally, the insulating material could not be applied throughout but limited to a single room and the walls could not be used as thermal storage. Figure 6(a) shows the variation in energy demand by varying insulation thickness. It was noticed that the energy demand changed more rapidly for attic insulation as compared to wall insulation. Figure 6(b) shows a change of $1 \mathrm{ACH}$ changes the energy demand by more than $3700 \mathrm{kWh}$. It was noted that demand in energy varies linearly when the air infiltration in the building was varied. 

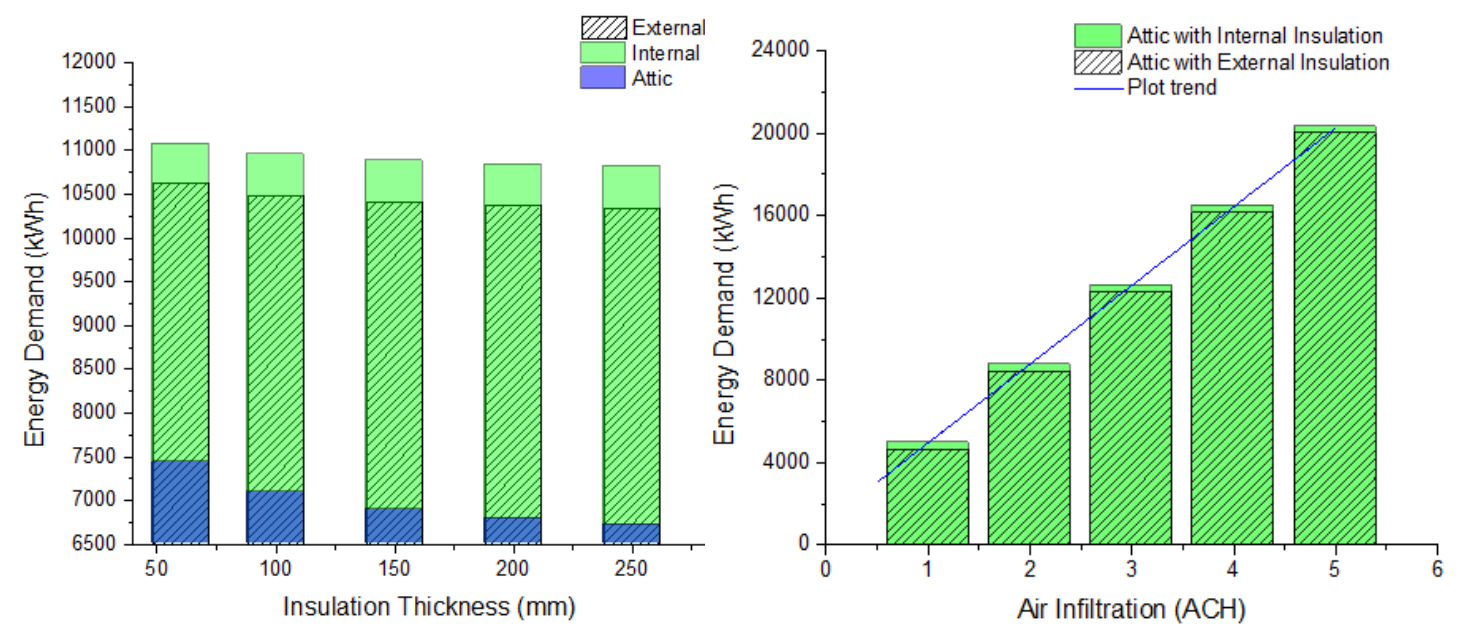

Figure 6. Parametric study result for (a) insulation thickness and (b) air infiltration

\subsection{Financial analysis}

The subsequent cost of energy demand was calculated using the low voltage (LV) consumer energy tariff set by the power distribution company, BPC (Bhutan Power Corporation), for 2017. A simple payback period was calculated to see the return on different options of insulation.

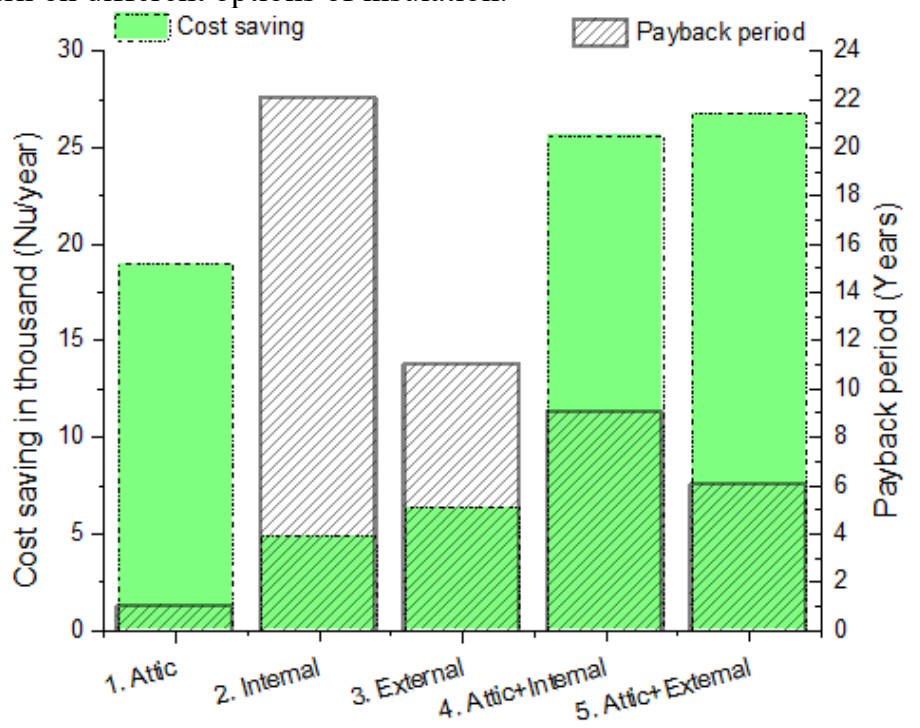

Figure 7. Cost savings vs. payback period different scenarios

The relationship between cost savings in Nu/year and payback period in years is depicted in Figure 7. The simulation suggests that attic insulation has the lowest payback period. Scenario-2 and 3 have a minimal difference in energy savings however, the payback period for Scenario-2 is two times more than that of scenario-3. It could be due to the cost of material used for insulation. In Scenario-2 gypsum board was used over the XPS insulation which added the cost of insulation. Table 9 summarizes the different scenarios to judge for the amount of savings and investment for different insulation intervention. 
Table 9. Cost of energy and payback period for different scenarios

\begin{tabular}{|c|c|c|c|c|c|c|c|}
\hline Scenario & $\begin{array}{c}\text { Energy } \\
\text { demand } \\
\text { (kWh/year) }\end{array}$ & $\begin{array}{c}\text { Energy } \\
\text { cost } \\
\text { (Nu/Year) }\end{array}$ & $\begin{array}{c}\text { Energy } \\
\text { savings } \\
\text { (kWh/year) }\end{array}$ & $\begin{array}{c}\text { Cost } \\
\text { savings } \\
\text { (Nu/year) }\end{array}$ & $\begin{array}{c}\text { Cost } \\
\text { savings } \\
\left(\mathrm{Nu} / \mathrm{m}^{2} \text { per }\right. \\
\text { year) }\end{array}$ & $\begin{array}{c}\begin{array}{c}\text { Cost of } \\
\text { insulation } \\
\left(\mathbf{N u} / \mathbf{m}^{2}\right)\end{array}\end{array}$ & $\begin{array}{c}\text { Payback } \\
\text { period } \\
\text { (years) }\end{array}$ \\
\hline Base case & 12491.55 & 0.00 & $40,062.02$ & - & - & - & - \\
\hline 1 & 6894.11 & 44.81 & $21,062.06$ & $5,597.44$ & 192.46 & 193.46 & 1 \\
\hline 2 & 11067.73 & 11.40 & $35,178.32$ & $1,423.82$ & 43.93 & 950.86 & 22 \\
\hline 3 & 10626.38 & 14.93 & $33,664.49$ & $1,865.17$ & 57.55 & 625.86 & 11 \\
\hline 4 & 4938.64 & 60.46 & $14,432.18$ & $7,552.91$ & 122.11 & 1130.86 & 9 \\
\hline 5 & 4588.56 & 63.27 & $13,303.31$ & $7,902.99$ & 127.49 & 805.86 & 6 \\
\hline
\end{tabular}

The payback period for insulation at different air insulation was also calculated as shown in Figure 8 . The payback period increases significantly as the air infiltration increases. Air infiltration above $3 \mathrm{ACH}$ has high energy demand that insulating the house with a given insulation thickness of $150 \mathrm{~mm}$ of rock wool for attic and $60 \mathrm{~mm}$ of XPS on the wall becomes inconsequential. The base case energy demand was $12,491.55 \mathrm{kWh}$. As the air infiltration in the building increases, the energy demand also increases and surpasses the base case energy demand for air infiltration rate beyond $3 \mathrm{ACH}$.

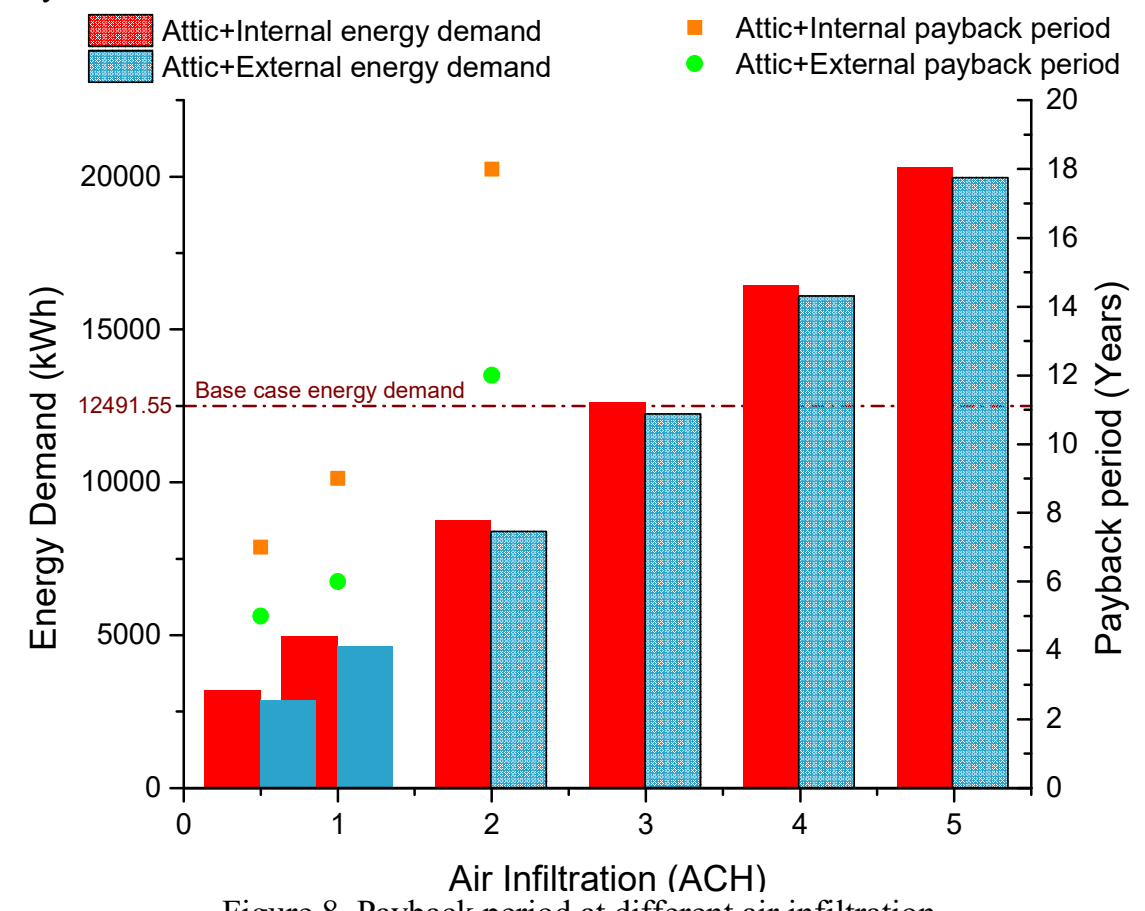

Figure 8. Payback period at different air infiltration

The effectiveness of energy efficiency in the building through insulation is studied through building energy modeling and simulation. In doing so, it was deduced that the accuracy of a software simulation depends on the intricacies of software that it is built upon. The simulation was conducted and validated with temperature for one room. The building could have been validated more precisely with other rooms as well if the measurement was available. It was also seen during the simulation that infiltration is a determining factor when the thermal performance of the building is concerned. It was noticed during the calibration of the building that varying the infiltration rate changed the energy demand drastically.

The payback period of above 22 years from the insulation of only the external wall on the inside seems long for house owners and construction planners compared to one year for only attic insulation. The energy reduction and payback period may not be consistent with a different type of buildings. Different buildings might have different building operational characteristics and different building material properties. The above-obtained result is restricted to multi-flat residential buildings in Thimphu and the type and method of insulation adopted for simulation. The measure of the payback period for this arrangement of the scenario presented is also prone to variation depending on the availability of materials and the location of the building site which adds cost to the project and determines its financial feasibility.

Energy saving in heating cannot be done by just insulating a part of the building envelope. The knowledge of what type of insulation is required and its application is very important. A house owner may invest a significant amount of money in such intervention resulting in insignificant returns. The period of return is vastly dependent 
on the cost and installation of the insulation material.

There is no limit to the level of insulation to put in a building but a good comparison must be made to balance indoor thermal comfort, cost, and local building standards. Simple attic insulation using rock wool insulation material was used for the building in this study and the significant result was achieved. The same may not be true for all buildings and different types of insulation. Retrofitting a poorly performing building is important in terms of the thermal comfort of the occupants and the energy required for heating. This study used energy simulation to compare basic types and methods of thermal insulation retrofitting in a residential building in a cold climate on Bhutan.

It is established that thermal insulation provides better thermal comfort in a house. When it comes to implementing such measures, the cost of implementation provides the deciding factor in selecting the type of energy retrofit. Any retrofit planner needs to consider the factors discussed such as type of insulation, the thickness of insulation, method of insulation, and investment.

Through this study, it was deduced that attic insulation is best out of the tested scenarios discussed earlier. The result obtained from the simulation is prone to factors such as insulation thickness and air infiltration. The airtightness of the building must be taken care of before opting for insulation. The thickness of the insulation could be selected as per the local building standards that would suggest the desired level of comfort in a building.

When considering the building envelope from weather, moisture transfer has to be considered as it determines the lifespan of insulation and related structures to fail if not done properly. Therefore, moisture/ vapour barrier or breathable material is recommended wherever appropriate. However, the study on the effect of moisture on insulation was not covered in this paper.

Simulation results show that exterior retrofits have a favorable position over internal retrofit regarding energy performance. The energy-efficient retrofit approach to building renovation has many methods based on the airtightness and thermal barrier of the envelope. Different studies could be carried out on building energy thermal performance concerning, type of insulation material, the thickness of insulation, the method of insulation, the cost of insulation, and building airtightness. Hence, understanding these variables makes the retrofitting project successful by aiding in making wiser decisions. Therefore, this study was focused on implementing such measures with the given knowledge of the concept, however, not focusing on a particular set of above-stated variables.

\section{Conclusions}

Retrofitting a poorly performing building is important in terms of the thermal comfort of the occupants and the energy required for heating. This study used energy simulation to compare basic types and methods of thermal insulation retrofitting in a residential building in a cold climate on Bhutan. It is established that thermal insulation provides better thermal comfort in a house. When it comes to implementing such measures, the cost of implementation provides the deciding factor in selecting the type of energy retrofit. Any retrofit planner needs to consider the factors discussed such as type of insulation, the thickness of insulation, method of insulation, and investment.

It was deduced that attic insulation is best out of the tested scenarios discussed earlier. The result obtained from the simulation is prone to factors such as insulation thickness and air infiltration. The airtightness of the building must be taken care of before opting for insulation. The thickness of the insulation could be selected as per the local building standards that would suggest the desired level of comfort in a building. When considering the building envelope from weather, moisture transfer has to be considered as it determines the lifespan of insulation and related structures to fail if not done properly. Therefore, moisture/vapour barrier or breathable material is recommended wherever appropriate. However, the study on the effect of moisture on insulation was not covered in this paper.

\section{References}

Accounting Tools. (2019). Payback Method | Payback Period Formula. Retrieved from Accounting Tools: https://www.accountingtools.com/articles/2017/5/17/payback-method-payback-period-formula

Chimack, M. J., Walker, C. E., \& Franconi, E. (2001). Determining Baseline Energy Consumption and Peak Cooling Loads of a 107-Year-Old Science Museum Using DOE 2.1E. Seventh International IBPSA Conference (p. 193). Rio de Janeiro: Building Simulation.

DRE. (2015). Bhutan Building Energy Efficiency Study. Thimphu: Department of Renewable Energy, Royal Government of Bhutan.

IEA. (2019, May Thursday). International Energy Efficiency. Retrieved from Energy Efficiency: /www.iea.org/topics/energyefficiency/buildings/

India Mart. (2019, August). Insulation Rock Wool. Retrieved from Insulators and Insulation Materials: www.indiamart.com/proddetail/loft-insulation-roll-9673396548.html

India Mart. (2019, August). Thermal Insulation Boards. Retrieved from Insulators and Insulation Materials: www.indiamart.com/proddetail/xps-thermal-insulation-board-14458997630.html 
Jentsh, M. F., Kulle, C., Bode, T., Pauer, T., Osburg, A., Tenzin, N. K., . . Tenzin, K. (2017). Field Study of the Building Physics Properties of Common Types in the Inner Himalayan Valleys of Bhutan. Energy for Sustainable Development, 58.

NSB. (2017). Bhutan Living Standards Survey Report. Thimphu: National Statistical Bureau, Royal Government of Bhutan.

Straube, J. F., Uneu, K., \& Schumacher, C. J. (2012). Measure Guideline: Internal Insulation of Masonry Walls. Oak Ridge, TN: U.S. Department of Energy.

Zhivov, A., Lohse, R., Shonder, J., Nasseri, C., Staller, H., Moerck, O., \& Nokkala, M. (2015). Business and Technical Concepts for Deep Energy Retrofits of Public Buildings. ASHRAE Transactions, Volume 121, Part 2, 126 . 